\title{
Pengenalan Macam - Macam Perkembangan dan Karakteristik Anak di Desa Sebuntal Marang Kayu
}

\author{
Nurul Hikmah \\ UWGM Samarinda \\ Program Studi PGSD, FKIP, Universitas Widya Gama Mahakam Samarinda \\ *e-mail: nuruluwgm@gmail.com
}

\begin{abstract}
Development is change that is owned by humans. Development is also a process through which to reach adulthood. The problems that occur in children in Sebuntal Marang Kayu Village are: the development and character of children is very worrying or worrying. This can be seen in the daily activities of children at school and at home that do not show good character. The purpose of this activity is to disseminate information in the field of education, provide information and knowledge to parents and children, related to child development. The result of this community service activity is that the activities can run smoothly. This activity received a friendly welcome, there was evidence that many participants were present, active, remained at the activity location until it was finished. This activity is useful in providing cognitive aspects and deeper understanding. This activity is a motivation for mothers, fathers and children in monitoring their children's attitudes. So, this activity is the most important part of increasing awareness for the community in guiding children's development.
\end{abstract}

Keywords: Development, Characteristics, Children, Parents

\begin{abstract}
Abstrak
Perkembangan adalah perubahan yang dimiliki oleh manusia. Perkembangan juga merupakan suatu proses yang dilewati untuk mencapai dewasa. Permasalahan yang terjadi pada anak di Desa Sebuntal Marang Kayu yaitu: perkembangan dan karakter anak sangat mengkhawatirkan atau memprihatinkan. Hal ini bisa dilihat pada aktivitas sehari-sehari anak di sekolah dan di rumah yang kurang menunjukan karakter yang baik. Tujuan kegiatan ini adalah untuk mensosialisasikan dalam bidang pendidikan, memberikan informasi dan pengetahuan kepada para orangtua dan anak, terkait dengan perkembangan anak. Hasil dilaksanakan kegiatan pengabdian kepada masyarakat ini yaitu kegiatan bisa berjalan dengan lancar. Aktivitas ini memperoleh sambutan yang ramah, adanya bukti dengan peserta banyak hadir, aktif, tetap di lokasi kegiatan sampai selesai. Kegiatan ini berguna dalam memberikan aspek kognitif dan pemahaman yang lebih mendalam. Aktivitas ini menjadi suatu motivasi bagi para ibu, bapak dan anak dalam mengawasi sikap anaknya. Jadi, aktivitas ini menjadi bagian terpenting untuk meningkatkan rasa sadar bagi masyarakat dalam membimbing perkembangan anak.
\end{abstract}

Kata Kunci : Perkembangan, Karakteristik, Anak, Orangtua

\section{PENDAHULUAN}

Dalam perkembangan dunia pendidikan, perkembangan anak termasuk perkembangan sosial dan emosional menempati posisi yang utama selain perkembangan kognitif anak. Karena perkembangan anak tersebut memiliki pengaruh pada lingkungan sekolah, keluarga dan masyarakat. Perkembangan pada anak tersebut memiliki pengaruh terhadap sikap, pengendalian, penyesuaian dan aturan-aturan. Apabila anak dapat beradaptasi maka fungsi sosial emosionalnya akan sangat bagus bisa dikendalikan. Perkembangan berlangsung dengan berkelanjutan mulai dari pembuahan sampai kematian, tetapi ini terjadi dengan bermacam volume, bisa lambat atau cepat. Pada setiap bidang perkembangan, bisa tercapai puncak pada usia tertentu. Contohnya imajinasi kreatif bisa terlihat pada masa TK dan tercapai puncak pada masa remaja. Perkembangan terus berjalan sebagaimana seharusnya apabila ada bantuan berbentuk stimulus dari lingkungan sekitar. Contohnya bapak dan ibu selalu mengajak anaknya berkomunikasi, maka makin cepat anak belajar bicara. Setiap hari orangtua bertanya kabar dan bertanya nama-nama buah kepada anaknya. Menjelang tamat Taman Kanak-kanak, anak tersebut suka aktif bicara. 
Pada perkembangan sosial dan emosional tidak seluruh anak bisa menghadapi perkembangan secara baik, karena anak menghadapi masalah dalam mengembangkan sosial dan emosional. Orang tua harus bisa mempengaruhi terhadap perkembangan sosial dan emosi anak dengan upaya memberikan bimbingan serta memberikan arahan pada perkembangan sosial dan emosional anak supaya tercapai perkembangan sesuai harapan. Pola perkembangan dikatakan sama pada seluruh anak. Ada perkembangan anak yang lancar dan anak lain terjadi penyimpangan. Dikarenakan masing-masing individu mempunyai perbedaan unsur biologis dan genetik. Selanjutnya faktor lingkungan memberikan kontribusi kepada perkembangan seorang anak.

Tahap berkembangnya anak sangat penting untuk dipahami ketika dilaksanakannya kegiatan belajar mengajar. Baik didalam keluarga kita sebagai orang tua atau kapasitas kita sebagai seorang pendidik. Orangtua merupakan orang yang pertama mendidik dan pertama dalam lingkungan keluarga, orang tua harus menyadari, anak mempunyai kemampuan besar saat dilahirkan. Betapa penting pendidikan anak usia dini dikarenakan pada periode itu perkembangan anak berjalan semakin pesat. Pada periode itu yaitu periode yang cocok dalam meletakkan dasar pendidikan karakter yang sesuai dengan perkembangannya. Agat tercapai, jadi dibutuhkan perjuangan besar dari orangtua untuk memberikan didikan atau membimbing anak ke semua aspek pengembangannya. Semua orangtua mempunyai harapan kepada setiap tahap perkembangan anak. Apabila tahap itu dapat dicapai, orangtua menjadi senang. Contohnya ada yang umur 1 tahun sudah bisa jalan, apabila sampai usia itu anak tidak dapat jalan, orangtua menjadi khawatir dan penuh tanda tanya.

\section{Pengertian Perkembangan}

(Samio, 2018) menjelaskan bahwa perkembangan lebih menuju adanya psikis yang berubah dimana perubahan itu terjadi karena dari kekuatan intern secara otomatis dan kekuatan dari luar. (Wulandari et al., 2017) mengungkapkan bahwa pertumbuhan dan perkembangan anak dipengaruhi oleh faktor eksternal dari anak. Sedangkan menurut Monks dalam (Latifa, 2017) juga menjelaskan arti dari perkembangan berkaitan dengan proses menuju hal sempurna. Kemudian menurut Chaplin (Latifa, 2017) mengemukakan bahwa perkembangan adalah perubahan pada organisme mulai lahir sampai mati, adanya pertumbuhan dan perubahan sampai menjadi dewasa.

Hampir sama (sependapat) kepada pendapat menurut (Somantri, 2012) perkembangan merupakan perubahan kualitatif yang artinya perubahan yang progresif, koheren dan teratur. Kemudian menurut Libert dalam (Sunarto, 2013) perkembangan yaitu proses yang berubah pada pertumbuhan sebagai manfaat kematangan dan interaksi pada lingkungan. Selanjutnya (Wiyani, 2014) menjelaskan bahwa perkembangan didefiniskan sebagai kemajuan menuju kedewasaan (psikis). (Handayani et al., 2017) menjelaskan bahwa anak adalah aset yang berharga suatu bangsa, sebab merupakan generasi penerus. Kurangnya perhatian karena orang tua sibuk kerja mengakitbatkan anak memiliki resiko menghadapi penyimpangan tumbuh kembang.

Disimpulkan bahwa perkembangan anak yaitu perubahan-perubahan yang dimiliki oleh anak atau manusia. Perkembangan juga merupakan suatu proses yang dihadapi anak atau mahluk hidup dalam tercapainya menjadi dewasa atau kesempurnaan secara fisiologis. Contohnya perkembangan yaitu perubahan fisik, kognitif, bahasa, emosi, sosial, moral. Selain itu contohnya yaitu manusia yang mulai dapat berbicara dan berjalan. Kemudian, bisa diantisipasi juga mengenai upaya dalam mencegah berbagai permasalahan yang dapat menghambat perkembangan anak terutama siswa SD. Setiap orang mempunyai kelebihan dan kekurangan seperti siswa SD. Ada yang mempunyai kelebihan dalam hal akademik tetapi rendah dalam non akademik, siswa yang memiliki kelebihan dalam aspek pengetahuannya namun rendah dalam aspek sosial begitupun sebaliknya. Itu dikarenakan ada dua faktor, adalah faktor gen dan lingkungan. 


\section{Masa Perkembangan Anak}

Selanjutnya (Aghnaita, 2017) anak yang memiliki perkembangan dilihat dari perkembangan fisik-motorik, sosial-emosional, moral keagamaan, dan pengetahuan. (Murni, 2017) menjelaskan bahwa masa TK yaitu masa perkembangan dari usia 2-6 tahun. Berkembangnya pengetahuan, anak dalam hal ini otaknya dapat meningkatkan kompetensi untuk berfikir, belajar dan mengingat. (Sujiono et al., 2014) juga menjelaskan bahwa masa lima tahun keadaan fisik maupun semua kemampuan anak sedang berkembang pesat. (Burhaein, 2017) mengungkapkan umur anak SD adalah melanjutkan setelah masa emas (umur muda). Maka dibutuhkan konsep belajar atau kegiatan menyesuaikan umur tumbuh kembangnya. Berdasarkan karakteristik anak usia SD suka bermain, bergoyang, berkelompok, dan mempraktikkan. Bentuk aktifitas fisik disesuaikan dengan jenjang usianya: tahap usia 7-8 tahun (SD kelas 1 dan 2), usia 9 tahun (SD kelas 3), usia 10-11 tahun (kelas 4 dan 5), dan usia12-13 tahun (kelas 6). Maka, dengan adanya kegiatan fisik yang tepat dan sesuai tahap, harapannya pertumbuhan fisik dan emosi bisa optimal.

\section{Jenis Perkembangan Anak}

Menurut Suyadi (Tusyana, 2019) perkembangan sosial dan emosional yaitu teori yang tidak bisa terpisah dan berkaitan. Kemudian Bloom dalam (Widianto, 2015) juga mengungkapkan bahwa perkembangan intelegensi, kepribadian dan perilaku sosial berkembang pesat apabila posisi anak pada masa usia muda. Usia muda seperti itu, peran orangtua sangat penting atau peran utama dalam meningkatkan pendidikan karakter bagi anak usia muda. Selanjutnya menurut (Soemanto, 2006) perkembangan yaitu suatu perubahan yang bersifat kualitatif. Selanjutnya (Nurmalitasari, 2015) menjelaskan bahwa perkembangan sosial emosi makin dipahami sebagai sebuah krisis dalam perkembangan anak. Itu diakibatkan karena anak terbentuk dengan sebuah perkembangan dalam proses pembelajaran.

\section{Karakteristik Anak}

Zubaidi dalam (Cahyaningrum, 2017) menjelaskan bahwa karakter adalah menandai dan memfokuskan, bagaimana mempraktikkan nilai kebaikan pada bentuk sikap. Anak mempunyai karakter yang bisa diamati sejak ia kecil dan bisa berkembang apabila ia dewasa sesuai dengan yang dialaminya. Menurut (Sunarto, 2013) setiap anak mempunyai ciri, karakteristik bawaan dan karakteristik yang didapat dipengaruhi oleh lingkungan. Pembentukan karakter tidak dapat dilaksanakan secara maksimal oleh sekolah tanpa kerjasama dari orangtua. Orangtua adalah orang yang mendidik pertama dan utama bagi anak serta menjadi dasar penting dalam membentuk karakter anak. Penanaman nilai-nilai pendidikan karakter bisa lebih berarti jika nilai tersebut bisa diimplikasikan dalam kehidupan sehari-hari. Oleh sebab itu, nilai pendidikan karakter lebih diutamakan pada kebiasaan anak dalam melaksanakan hal-hal yang positif dan keteladanan atau contoh yang diperlihatkan oleh orangtua. Kebiasaan-dan keteladanan inilah yang selanjutnya dapat menjadi suatu karakter terdapat dalam jiwa sang anak.

\section{Peran Orangtua}

Orang tua menjadi peran utama untuk mempengaruhi anak pada saat anak peka dengan lingkungan luar, dan mengajarkan anak dengan cara yang bervariasi. Orang tua yaitu orang paling utama mengenal kapan dan bagaimana anak belajar secara sungguh-sungguh (Mutmainnah, 2012). Ada beberapa alasan bahwa orangtua harus memahami perkembangan anak. Alasan-alasan tersebut adalah seperti : memahami aspek perkembangan dan faktor yang mempengaruhi perkembangan anak.

\section{METODE}

Metode dalam pengabdian masyarakat ini berupa workshop yang terdiri dari perencanaan, persiapan, pelaksanaan dan evaluasi. 


\section{HASIL DAN PEMBAHASAN}

\section{Hasil}

Pengabdian masyarakat ini merupakan program tridarma, yang penyaji materinya telah dari seorang dosen UWGM Samarinda, FKIP, Prodi PGSD. Kegiatan pengabdian masyarakat ini telah dilakukan dengan acara tatap muka bertemu secara langsung. Sosialisasi tentang Pengenalan Macam-macam Perkembangan dan Karakteristik serta Cara Mengatasi Permasalahan Anak Kepada Orangtua di Desa Sebuntal Marang Kayu telah dilaksanakan pada bulan Februari tahun 2020, dukungan dari berbagai pihak telah memberikan kemudahan pada tim pengabdi untuk melaksanakan kegiatan ini dengan baik. Setelah sebelumnya mengadakan koordinasi dengan perwakilan warga di Desa Semangko (Marang Kayu, Kukar), yaitu Bapak H. M. Noor. Asamad. Dalam kegiatan tersebut ketua tim pengabdi menjelaskan materi tentang Pengenalan Macam-macam Perkembangan dan Karakteristik serta Cara Mengatasi Permasalahan Anak Kepada Orangtua yang asal daerahnya dari Samarinda dan dari Desa Semangko tuk bergabung ikut kegiatan yang lokasinya di Desa Sebuntal Marang Kayu. Kegiatan pengabdian ini berlangsung dengan lancar dan sistematis sesuai dengan apa yang direncanakan. Semua peserta sangat aktif dalam menjawab atau merespon materi yang dijelaskan ketua tim pengabdi.

\section{Pembahasan}

Kegiatan pengabdian pada masyarakat yang berupa sosialisasi tentang Pengenalan Macam-macam Perkembangan dan Karakteristik serta Cara Mengatasi Permasalahan Anak Kepada Orangtua, di Desa Sebuntal Marang Kayu merupakan lokasi dilakukannya kegiatan pengabdian. Contohnya telah dijelaskan bahwa Desa Sebuntal Marang Kayu adalah wilayah yang bisa disebut jauh dari pusat kota, dari Samarinda sampai ke Desa Sebuntal sekitar 3 (tiga) jam. Bisa dikatakan agak terpencil. Kegiatan pengabdian masyarakat ini dilaksanakan di rumah warga Desa Sebuntal.

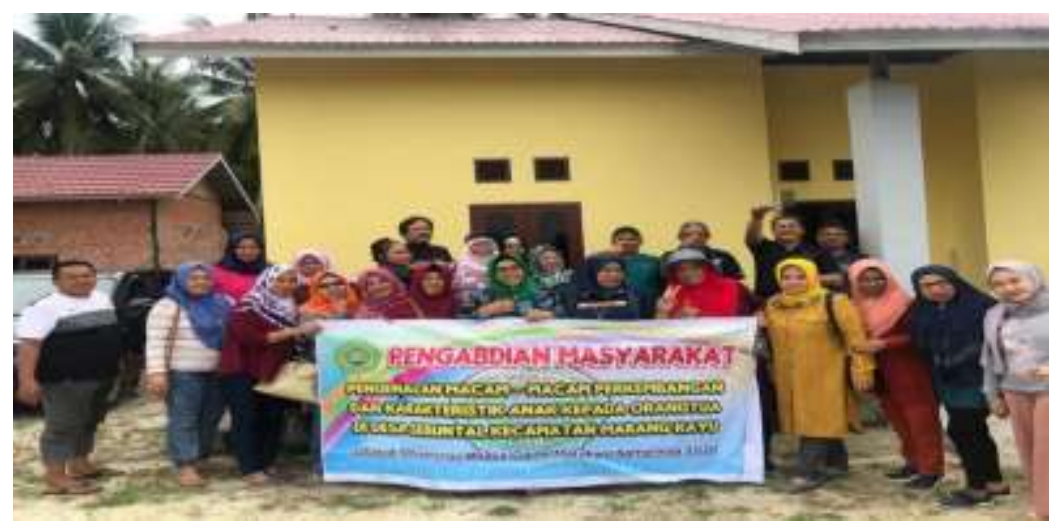

Gambar 1. Foto Bersama Peserta Setelah Pelaksanaan Workshop

Dalam pelaksanaan pengabdian ini, kegiatan ini diikuti oleh 30 peserta. Peserta yang mengikuti ada yang asal daerah dari Kota Samarinda dan ada yang dari Desa Sebuntal Marang Kayu (Kukar).Maka bisa disebut bahwa target peserta mencapai seratus persen. Angka itu membuktikan bahwa kegiatan ini bisa dilihat dari banyaknya peserta yang ikut hadir sosialisasi bisa disebut berhasil. Kegiatan diskusi ini berlangsung dengan sistematis dan lancar. Peserta memperlihatkan rasa antusiasmenya dengan mengajukan beberapa pertanyaan. Peserta juga memberikan nuansa partisipatif yang tinggi dalam kegiatan ini. Kemampuan awal peserta dalam memahami materi ada yang masih kurang, ada yang sudah cukup baik dan kemudian tim pengabdi menjelaskan materi, kemampuan tim pengabdi dinilai dalam menyajikan materi sudah baik. Peserta dapat menyerap dan merespon materi yang disampaikan oleh tim pengabdi yang berkaitan dengan sosialisasi tentang pengenalan macam-macam perkembangan dan karakteristik serta cara mengatasi permasalahan anak kepada orangtua, di Desa Sebuntal Marang Kayu. 
Pelaksanaan dalam kegiatan pengabdian masyarakat ini cukup baik, pokok bahasan sosialisasi ini sudah disampaikan secara keseluruhan. Pokok bahasan sosialisasi yang sudah dijelaskan yaitu tentang : konsep dasar perkembangan, pengertian prinsip-prinsip perkembangan, pengertian karakteristik perkembangan, tahap-tahap perkembangan, macammacam perkembangan (perkembangan fisik, sosial, emosi dan bahasa), masalah perkembangan anak dan cara mengatasi permasalahan anak.

\section{KESIMPULAN}

Program pengabdian ini mengenai Pengenalan Macam-macam Perkembangan dan Karakteristik serta Cara Mengatasi Permasalahan Anak Kepada Orangtua, di Desa Sebuntal Marang Kayu, sangat penting bagi dalam rangka meningkatkan kemampuan orangtua dan anak,, materi yang dijelaskan dinilai sangat bermanfaat dan dapat dilaksanakan diterapkan kepada anak. Berdasarkan penjelasan hasil pelaksanaan kegiatan pengabdian kepada masyarakat maka tim pengabdi menyimpulkan bahwa kegiatan pengabdian berupa sosialisasi tentang Pengenalan Macam-macam Perkembangan dan Karakteristik serta Cara Mengatasi Permasalahan Anak Kepada Orangtua, di Desa Sebuntal Marang Kayu bisa berjalan lancar sesuai rencana.

Pengabdian ini memperoleh tanggapan yang ramah, adanya bukti dengan peserta yang aktif dengan tetap bertahan di lokasi kegiatan sebelum acara selesai. Kegiatan ini juga sangat berguna dalam memberikan aspek kognitif dan pemahaman yang lebih mendalam mengenai pentingnya melihat, mengawasi dan membimbing perkembangan sikap anak-anaknya. Kegiatan ini menjadi motivasi bagi para ibu, bapak dan anak untuk menyampaikan informasi khususnya kepada ibu, bapak dan anak lain yang tidak bergabung dalam kegiatan pengabdian ini agar terus mengawasi sikap anak-anaknya. Dengan demikian kegiatan sosialisasi ini menjadi bagian penting dalam meningkatkan rasa sadar bagi masyarakat dalam memperhatikan perkembangan anak.

\section{UCAPAN TERIMA KASIH}

Tim Pengabdian mengucapkan Terima Kasih kepada LPPM UWGM Samarinda yang telah memberikan bantuan dana untuk kegiatan pengabdian ini.

\section{DAFTAR PUSTAKA}

Aghnaita, A. (2017). Perkembangan Fisik-Motorik Anak 4-5 Tahun Pada Permendikbud no. 137 Tahun 2014 (Kajian Konsep Perkembangan Anak). AL-ATHFAL : JURNAL PENDIDIKAN ANAK.

Burhaein, E. (2017). Aktivitas Fisik Olahraga untuk Pertumbuhan dan Perkembangan Siswa SD. Indonesian Journal of Primary Education.

Cahyaningrum. (2017). Pengembangan Nilai-nilai Karakter Anak Usia Dini melalui Pembiasaan dan Keteladanan. Yogyakarta

Handayani, D. S., Sulastri, A., Mariha, T., \& Nurhaeni, N. (2017). Penyimpangan Tumbuh Kembang Anak dengan Orang Tua Bekerja. Jurnal Keperawatan Indonesia.

Latifa, Umi. (2017). Aspek Perkembangan pada Anak Sekolah Dasar: Masalah dan Perkembangannya. Surakarta.

Murni. (2017). Perkembangan fisik, kognitif, dan psikososial pada masa kanak-kanak awal 2-6 tahun. Jurnal Pendidikan Anak.

Nurmalitasari, F. (2015). Perkembangan Sosial Emosi pada Anak Usia Prasekolah. Buletin Psikologi. Samio, S. (2018). Aspek - Aspek Pertumbuhan Dan Perkembangan Peserta Didik. Best Journal (Biology Education, Sains and Technology).

Soemanto, Wasty. (2006). Psikologi Pendidikan. Jakarta : PT Rineka Cipta.

Somantri, Sutjihati. (2012). Psikologi Anak Luar Biasa. Bandung: PT Refika Aditama. 
Sujiono, B., Sumantri, M. S., \& Chandrawati, T. (2014). Hakikat Perkembangan Motorik Anak. Modul Metode Pengembangan Fisik.

Sunarto. (2013). Perkembangan Peserta Didik. Jakarta : Rineka Cipta.

Tusyana, Eka. (2019). Analisis Perkembangan Sosial-Emosional Tercapai Siswa Usia Dasar. Yogyakarta.

Widianto, Edi. (2015). Peran Orangtua dalam Meningkatkan Pendidikan Karakter Anak Usia Sini dalam Keluarga. Malang.

Wiyani, Novan Ardy. (2014). Buku Ajar Penanganan Anak Usia Dini Berkebutuhan Khusus. Yogyakarta : Ar-Ruzz Media.

Wulandari, R., Ichsan, B., \& Romadhon, Y. A. (2017). Perbedaan Perkembangan Sosial Anak Usia 36 tahun dengan Pendidikan Usia Dini dan Tanpa Pendidikan Usia Dini di Kecamatan Peterongan Jombang. Biomedika. 